\title{
Mercury and iron in atmospheric precipitation of the Azov Sea basin
}

\author{
Fedorov Yu.A.*, Mikhailenko A.V., Dmitrik L.Y., Dotsenko I.V., Solodko D.F., \\ Chepurnaya V.I.
}

Southern Federal University Bolshaya Sadovaya Str. 105/42, Rostov-on-Don, 344006, Russia

\begin{abstract}
In different seasons of the year, the iron and mercury concentration levels in liquid and solid phase were studied in the troposphere above the Azov Sea waters, its coasts, and some cities of the Rostov Region. These levels in hydrometeors depend on seasons, sampling places, wind activity, rain and snow precipitation.
\end{abstract}

Keywords: Azov Sea, cities, precipitation, iron, mercury, migration forms, distribution

Iron and mercury are the priority heavy metals, the content of which often exceeds the MPC in the surface waters of the Azov Sea. Precipitation is an important source of iron and mercury in the surface waters of the Azov Sea basin (Fedorov et al., 2002; Klenkin et al., 2007). $38 \%$ of iron and $28 \%$ of mercury (from their total input into this basin) are transported to the Azov Sea via precipitation. Mercury can enter the structure of sulfide minerals isomorphically - e.g., $\mathrm{Fe}_{2} \mathrm{~S}$ (Thomas, 1972; Gilles and Bancroft, 1986) and FeS * $\mathrm{nH}_{2} \mathrm{O}$ (Fedorov et al., 2019), or it can be adsorbed on their surface. Iron hydroxides are also sorbents for mercury. The above-said is the reason for considering precipitated mercury and iron together.

The data on iron and mercury concentrations obtained in the course of the expeditions in 20012002 and later in February 2020 have been analyzed (Fedorov et al., 2002). Rain and snow samples were carried out in the cities Rostov-on-Don (Ostrovsky Park), Taganrog, Azov, Shakhty, and Novocherkassk, and in the village of Margaritovo. The highest mercury concentrations were registered in precipitation in the cities Shakhty and Novocherkassk (from 0.43 to 0.82 $\mu \mathrm{g} / \mathrm{dm}^{3}$ ). In Rostov-on-Don, the precipitated mercury content varies during the year from 0.06 to $0.62 \mu \mathrm{g}$ / $\mathrm{dm}^{3}$. The maximum concentrations of this metal were registered in the precipitation samples taken in autumn and winter. In the coastal cities Azov, Taganrog, and the Margaritovo village, the precipitated mercury content in autumn was $0.20,0.26$, and $0.15 \mu \mathrm{g} / \mathrm{dm}^{3}$, respectively. According to Klenkin et al. (2007), the mercury content in the hydrometeors above the sea varied widely, i.e. from 0.06 to $0.60 \mu \mathrm{g} / \mathrm{dm}^{3}(0.24 \mu \mathrm{g}$ / $\mathrm{dm}^{3}$ on average), and that of iron varied from 0.01 to $0.39 \mathrm{mg} / \mathrm{dm}^{3}\left(0.1 \mathrm{mg} / \mathrm{dm}^{3}\right.$ on average). The maximum concentration changes for both mercury and iron were established in autumn. According to our calculations, the correlation between the mercury and iron content is weakly reverse. In winter 2020 , the total content of iron varied from 0.11 to $1.0 \mathrm{mg} / \mathrm{dm}^{3}\left(0.29 \mathrm{mg} / \mathrm{dm}^{3}\right.$ on average) in fresh and recrystallized snow, the total content of dissolved total iron $\left(\mathrm{Fe}_{\text {total }}\right)$ varied from 0.015 to $0.088 \mathrm{mg} / \mathrm{dm}^{3} \quad\left(0.048 \mathrm{mg} / \mathrm{dm}^{3}\right.$ on average), the content of suspended Fe varied from 0.052 to 0.095 $\mathrm{mg} / \mathrm{dm}^{3}\left(0.24 \mathrm{mg} / \mathrm{dm}^{3}\right.$ on average). The calculations also show that from 6.5 to $63 \%$ (on average $31 \%$ ) of iron occurs in snow in dissolved form. The maximum total contents of dissolved and suspended iron (4.1, 0.1, and $4.0 \mathrm{mg} / \mathrm{dm}^{3}$, respectively) were found in a sample of roadside dark-grey ice with frozen organomineral particles. This sample was essentially a conglomerate of roadside dust and ice, where $\mathrm{Fe}_{\text {total }}$ content was only $0.25 \%$ of the total content. The snow and ice $\mathrm{pH}$ values varied from 5.0 to 7.0 (6.1 on average). A reverse ratio is established between the $\mathrm{pH}$ values and $\mathrm{Fe}_{\text {total }}$ content.

In conclusion, it should be noted that there is an increasing tendency in the mercury concentrations in rain and snow sampled in the cities of the Rostov Region, compared to precipitation over the sea and its coast.The maximum mercury concentrations in the hydrometeors were found in the cities in autumn and winter. It is due to its penetration into the troposphere as a result of the rapidly increasing dust amounts and gas emissions sourced by combustion of coal, fuel oil, and gas during the hot season. According to Fedorov et al. (2002), the mercury concentrations are higher in stale snow, than in just-fallen snow. It is suggested that stale snow is a depositing material absorbing mercury from the troposphere, where it accumulates due to activity of various enterprises with pollutant emissions.

*Corresponding author.

E-mail address: fedorov@sfedu.ru (Yu. A. Fedorov) 
This statement is confirmed indirectly by the fact that the Donbass coals are characterized by high mercury concentrations (Rylov et al., 2012; 2016). Another mechanism could be mercury re-distribution during the compaction of snow cover and its interaction with soil. In the course of the winter expeditions, a clear snow stratification was registered: just-fallen powder and stale crystallized grey snow with a large amount of mineral and organic material. The dissolved and suspended forms of iron migration prevail in stale snow. The suspended iron content tends to exceed $\mathrm{Fe}_{\text {total }}$ from stale snow to just-fallen snow. According to our calculations using the data by Klenkin et al. (2007), there was no correlation between the mercury and iron content in rain precipitation above the sea area and on seasonality. Bursts of the maximum mercury and iron concentrations were typical for autumn. Wind activity and atmospheric precipitation affect the iron and mercury content in the hydrometeors. When wind activity increases, the atmosphere surface layers in the cities are enriched by technological substances, and the input of soil particles increases during dust storms. According to our observations, there is intensive mercury leaching from the atmosphere during torrential rains. It leads to a sharp decrease in its atmospheric concentrations. However, there is increase in the mercury content in the rainfall after a dry period under calm weather conditions.

\section{Acknowledgement}

The work was carried out with the financial support of the RFBR, project No. 19-05-00770 (Studying the iron content distribution), and the RF President
Grant No. MK-1862.2020.5 (Studying the mercury content distribution).

\section{References}

Fedorov Yu.A., Ovsepyan A.E., Savitsky V.A. et al. 2019. Mercury in the White Sea bottom sediments: distribution, sources, and deposition chronology. Okeanologiya [Oceanology] 59: 153-162. DOI: 10.31857/S00301574591153-162 (in Russian)

Fedorov Yu.A., Berezan O.A., Velichko M.L. et al. 2002. Distribution and mercury concentration levels in the atmosphere and water bodies of the Azov Sea. In: Averintsev V.G., Berdnikov S.V., Bufetova M.V. (Eds.), Ekosistemnyye issledovaniya Azovskogo morya i poberezh'ya [Ecosystem investigations of the sea of Azov and its coastal zone]. Apatity, pp. 150-166.

Gilles J.E., Bancroft G.M. 1986. Heavy metal adsorption by sulphide mineral surface. Geochimica et Cosmochimica Acta 50: 1455-1463. DOI: 10.1016/0016-7037(86)90319-4

Klenkin A.A., Korpakova I.G., Pavlenko L.F. et al. 2007. Ekosistema Azovskogo morya: antropogennoye zagryazneniye [Ecosystem of the Azov Sea: the anthropogenic pollution]. Krasnodar: AzNIIRH. (in Russian)

Rylov V.G., Fedorov Yu.A., Gamov M.I. 2012. Geological and structural zoning of the Eastern Donbas using data on mercury and methane content in the coal seams. Izvestiya Vysshikh Uchebnykh Zavedeniy. Severo-Kavkazskiy Region. Yestestvennyye Nauki [Bulletin of Higher Education Institutes. North Caucasus Region. Natural Sciences] 2: 107-111. (in Russian)

Rylov V.G., Fedorov Yu.A., Gamov M.I. 2016. The methane and mercury concentration distribution and their emission in the East Donbas. In: 16th International Multidisciplinary Scientific GeoConference SGEM 2016, pp. 701-706.

Thomas R.L. 1972. The distribution of mercury in the sediments of Lake Ontario. Canadian Journal of Earth Sciences 9: 636-651. DOI: 10.1139/e72-054 